\title{
New and noteworthy black mildews from the Western Ghats of Peninsular India
}

\section{Hosagoudar VB}

Jawaharlal Nehru Tropical Botanic Garden and Research Institute, Palode 695 562, Thiruvananthapuram, Kerala, India.

Hosagoudar VB 2013 - New and noteworthy black mildews from the Western Ghats of Peninsular India. Plant Pathology \& Quarantine 3(1), 1-10, doi 10.5943/ppq/3/1/1

Sixteen black mildews collected from different regions of Western Ghats are described. Of these, Amazonia symploci, Asteridiella fagraeae, Asterdiella hydnocarpigena, Asteridiella premnigena, Asteridiella tragiae, Asteridiella xyliae, Asterina tragiae, Asterina xyliae, Meliola celastrigena, Meliola glochidiifolia, Meliola goniothalamigena, Meliola jasminigena, Meliola phyllanthigena, Meliola pygeicola and Meliola tragiae are new species while Prillieuxina loranthi is reported for the first time from India.

Key words - Amazonia - Asterdiella - Asterina - Black mildews - Meliola - new species

\section{Article Information}

Received 29 September 2012

Accepted 14 October 2012

Published online 3 February 2013

*Corresponding author: VB Hosagoudar - e-mail - vbhosagoudar@ rediffmail.com

\section{Introduction}

I have been engaged in the collection, identification and documentation of the foliicolous fungi from India, in particular, Western Ghats. During the course of identification of these fungi many new species were found of which some are presented here.

\section{Methods}

Collection methodology and mounting techniques are in accordance with Hosagoudar (1996, 2008, 2012).

\section{Results}

\section{Taxonomy}

Amazonia symploci V.B. Hosagoudar sp. nov.

MB no. 803085 \section{Fig. $1 \mu \mathrm{m}$.} genus.

Etymology - Named after the host

Colonies amphigenous, subdense, scattered, up to $2 \mathrm{~mm}$ in diameter. Hyphae straight, substraight to slightly flexuous, branching opposite at acute to wide angles, loosely to closely reticulate, cells $14-19 \times 4-8$ $\mu \mathrm{m}$. Appressoria alternate to unilateral, straight to curved, antrorse to subantrorse, $14-21 \mu \mathrm{m}$; stalk cells cylindrical to cuneate, $4-8 \mu \mathrm{m}$ long; head cells globose, entire, 9-14 × 8-12 $\mu \mathrm{m}$. Phialides mixed with appressoria, alternate to opposite, ampulliform, 16-22 × 6-10 $\mu \mathrm{m}$. Perithecia scattered, flattened-globose with radiating cells, up to $150 \mu \mathrm{m}$ in diameter; ascospores oblong to cylindrical, 4-septate, slightly constricted at the septa, 35-40 × 16-19 


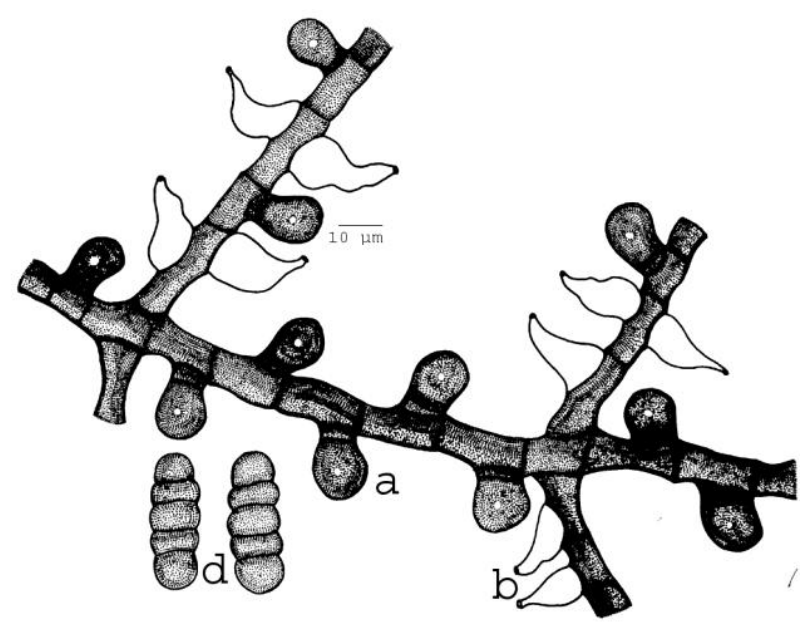

Fig. 1 - Amazonia symploci

Materials examined - Kerala, Palghat, Silent Valley National Park, Poochipara, on leaves of Symplocos sp. (Symplocaceae), 14 February 2007, M.C. Riju \& al. TBGT 6241 (holotype).

This is the first species of the genus Amazonia on the members of the family Symplocaceae (Hansford 1961, Hosagoudar 1996, 2008).

Asteridiella fagraeae V.B. Hosagoudar \& A. Sabeena sp. nov.

MB no. 803117

Fig. 2

Etymology - Named after the host genus.
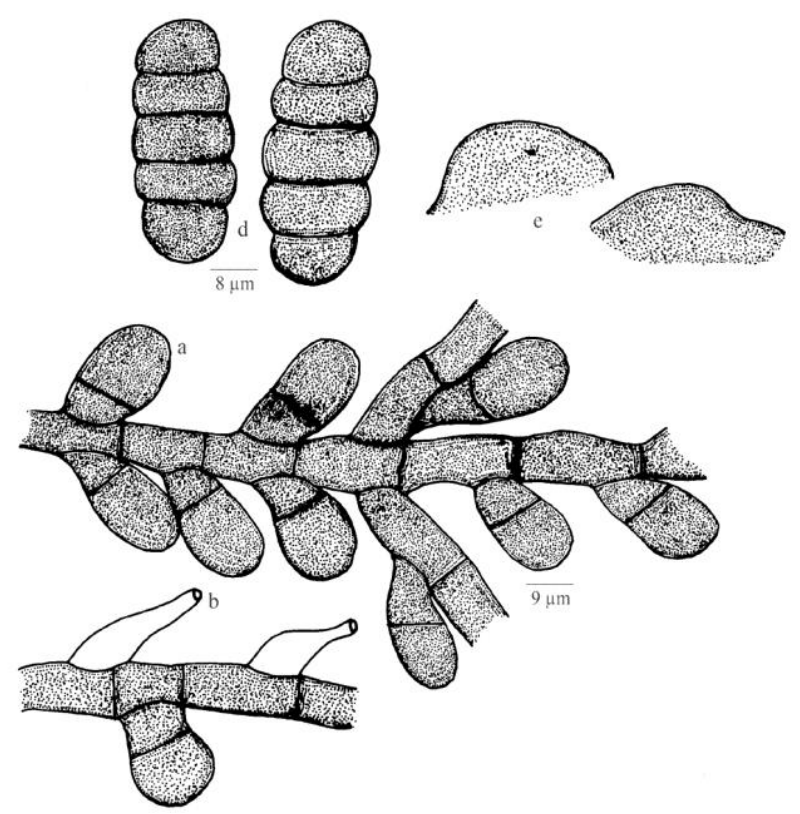

Fig. 2 - Asteridiella fagraeae
Colonies epiphyllous, subdense to dense, often velvety, up to $7 \mathrm{~mm}$ in diameter, confluent. Hyphae straight to substraight, branching opposite to unilateral at acute to wide angles, closely reticulate, cells $12-25 \times$ 5-10 $\mu \mathrm{m}$. Appressoria opposite, alternate to unilateral, antrorse to subantrorse, $15-25 \mu \mathrm{m}$ long; stalk cells cylindrical to cuneate, $2-7 \mu \mathrm{m}$ long; head cells globose, ovate, entire, $12-17 \times$ 10-12 $\mu \mathrm{m}$. Phialides few, mixed with appressoria, alternate, ampulliform, 20-25 ×6$8 \mu \mathrm{m}$. Perithecia scattered, up to $240 \mu \mathrm{m}$ in diameter; perithecial wall cells conoid to mammiform, up to $15 \mu \mathrm{m}$ long; ascospores oblong, 4-septate, constricted at the septa, 42$47 \times 16-18 \mu \mathrm{m}$.

Materials examined - Kerala, Palghat, Silent Valley National Park, Pulippara, on leaves of Fagraea ceilanica Thunb. (Loganicaceae), 14 February 2007, M.C. Riju TBGT 6237 (holotype).

Asteridiella implicata (Doidge) Hansf., A. nuxiae (Syd.) Hansf., A. obducens (Gaillard) Hansf., A. inermis (Kalchbr. \& Cooke) Hansf., A. anthocleistae (Hansf. \& Deighton) Hansf., A. buddleiae Hansf. and A. budleyicola (Henn.) Hansf. are known on members of the family Loganicaceae but the present new species differs from all in having opposite appressoria (Hansford 1961).

Asterdiella hydnocarpigena V.B. Hosagoudar \& C. Jagath Timmaih sp. nov. Fig. 3 MB no. 803118

Etymology - Named after the host genus.

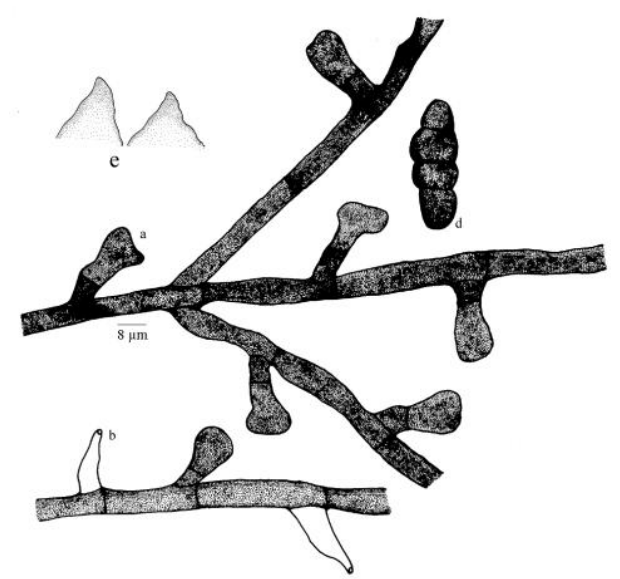

Fig. 3 - Asterdiella hydnocarpigena 
Colonies epiphyllous, thin, up to $4 \mathrm{~mm}$ in diameter. Hyphae straight to substraight, branching mainly opposite to rarely unilateral at acute to wide angles, loosely to closely reticulate, cells $25-42 \times 3-5 \mu \mathrm{m}$. Appressoria alternate to unilateral, antrorse to subantrorse, straight to curved, 15-20 $\mu \mathrm{m}$ long; stalk cells cylindrical to cuneate, 5-7 $\mu \mathrm{m}$ long; head cells ovate, clavate, entire, truncate, straight to curved, 7-15 × 5-15 $\mu \mathrm{m}$; perithecia scattered, flattened, globose, up to $105 \mu \mathrm{m}$ in diameter; ascospores bent, ellipsoidal, 3 septate, constricted at the septa, $20 \times 7 \mu \mathrm{m}$.

Materials examined - Karnataka, Kodagu, Madikeri, on leaves of Hydnocarpus pentendra (Ham.) Oken (Flacourtiaceae), 16 March 2010, C. Jagath Timmaih TBGT 6239 (holotype).

This species differs from all known Asteridiella species on members of Flacourtiaceae in having 3-septate ascospores with entire head cells of appressoria (Hansford 1961, Hosagoudar 1996, 2008).

Asteridiella premnigena V.B. Hosagoudar sp. nov.

MB no. 803119

Fig. 4

Etymology - Named after the host genus.

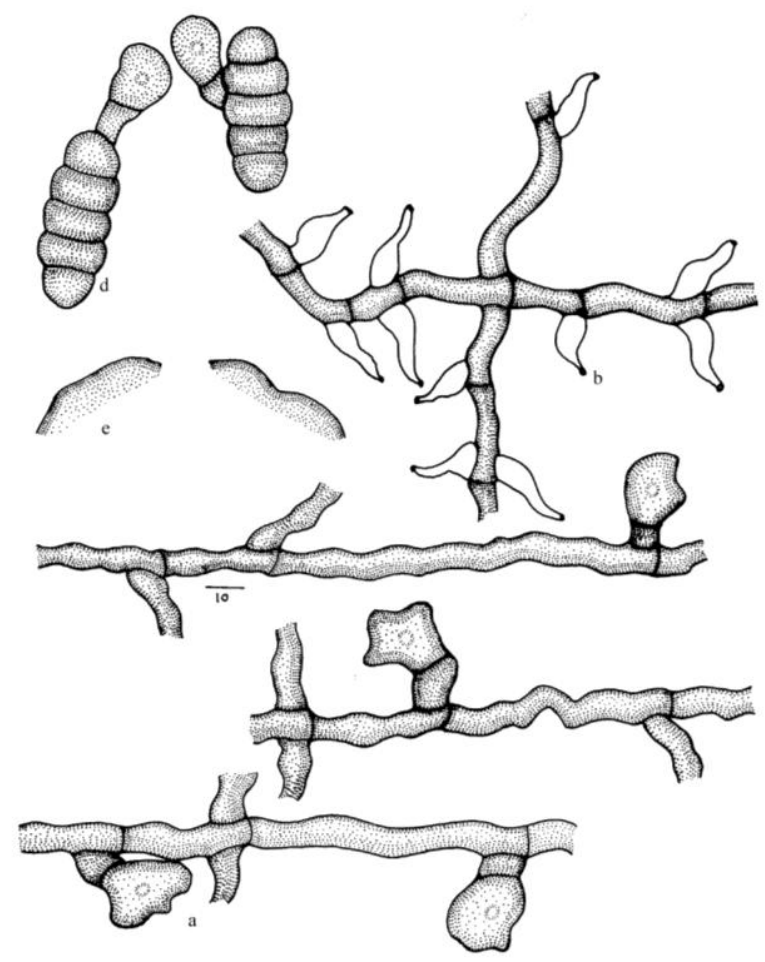

Fig. 4 - Asteridiella premnigena
Colonies epiphyllous, subdense, scattered, up to $2 \mathrm{~mm}$ in diameter. Hyphae slightly substraight to flexuous, branching alternate, opposite to irregular at acute to wide angles, loosely reticulate, cells 20-30 × 5-7 $\mu \mathrm{m}$. Appressoria alternate, unilateral, antrorse, subantrorse to retrorse, 19-31 $\mu \mathrm{m}$ long; stalk cells cylindrical to cuneate, $4-11 \mu \mathrm{m}$ long; head cells oblong, ovate, clavate, entire, angular to sublobate, often truncate at the apex, 14-19 × 9-15 $\mu \mathrm{m}$. Phialides borne on a separate mycelial branch, alternate to opposite, ampulliform, 16-19 × 6-8 $\mu \mathrm{m}$. Perithecia scattered, up to $120 \mu \mathrm{m}$ in diameter; ascospores oblong to ellipsoidal, 4-septate, slightly constricted at the septa, 33-38 × 12-16 $\mu \mathrm{m}$.

Materials examined - Kerala, Kottayam, Ponthanpuzha, on leaves of Premna sp. (Verbenaceae), 23 November 2009, P.J. Robin \& al. TBGT 6235 (holotype).

Asteridiella depokensis Hansf. is known on this host genus from Philippines but $A$. premnigena differs from it in having distantly placed appressoria and phialides borne on a separate mycelial branch. This species is mixed with the colony of Meliola premnicola Hosag.

Asteridiella tragiae V.B. Hosagoudar \& C. Jagath Timmaih sp. nov. MB no. 803120

Fig. 5

Etymology - Named after the host genus.

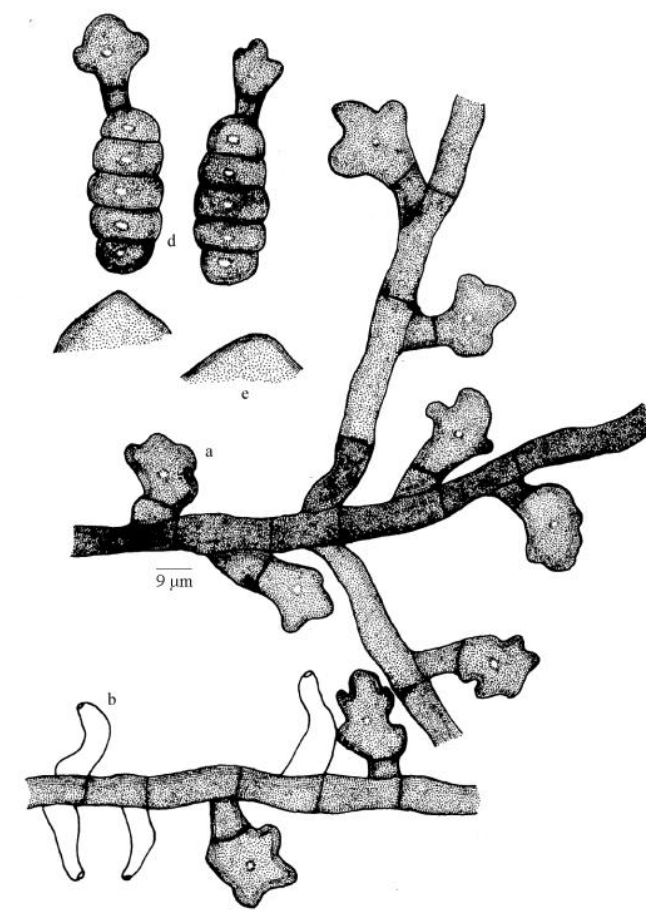

Fig. 5 - Asteridiella tragiae 
Colonies epiphyllous, subdense, spreading, up to $2 \mathrm{~mm}$ in diameter. Hyphae straight to substraight, branching mostly opposite to irregular at acute to wide angles, loosely to closely reticulate, cells $20-27 \times 3-5$ $\mu \mathrm{m}$. Appressoria alternate to unilateral, mostly straight to rarely curved, antrorse to subantrorse, 22-27 $\mu \mathrm{m}$ long; stalk cells cylindrical to cuneate, 7-10 $\mu \mathrm{m}$ long; head cells ovate to globose, stellately to irregularly sublobate to deeply lobate, $15-20 \times 12-20 \mu \mathrm{m}$. Phialides mixed with appressoria, opposite to alternate, ampulliform, 15-22 × 3-5 $\mu \mathrm{m}$. Perithecia scattered, up to $120 \mu \mathrm{m}$ in diameter; perithecial wall cells conoid to mammiform, up to $10 \mu \mathrm{m}$ long; ascospores oblong, cylindrical, 4-septate, constricted at the septa, 37-40 × 12$15 \mu \mathrm{m}$.

Materials examined - Karnataka, Kodagu, Medikari, on leaves of Tragia sp. (Euphorbiaceae), 1 January 2010, C. Jagath Thimmaiah TBGT 6238b (holotype).

Asteridiella phyllanthi (Deighton) Hansf., A. erythrococcae Hansf., A. hansfordii (F. Stevens) Hansf. and A. hansfordii var. densa (Hansf. \& Deighton) Hansf. come under the digital formula 3101.3220. However, A. tragiae differs from all in having lobate head cells of the appressoria (Hansford 1961).

Asteridiella xyliae V.B. Hosagoudar sp. Nov

MB no. 803121

Fig. 6 genus.

Etymology - Named after the host

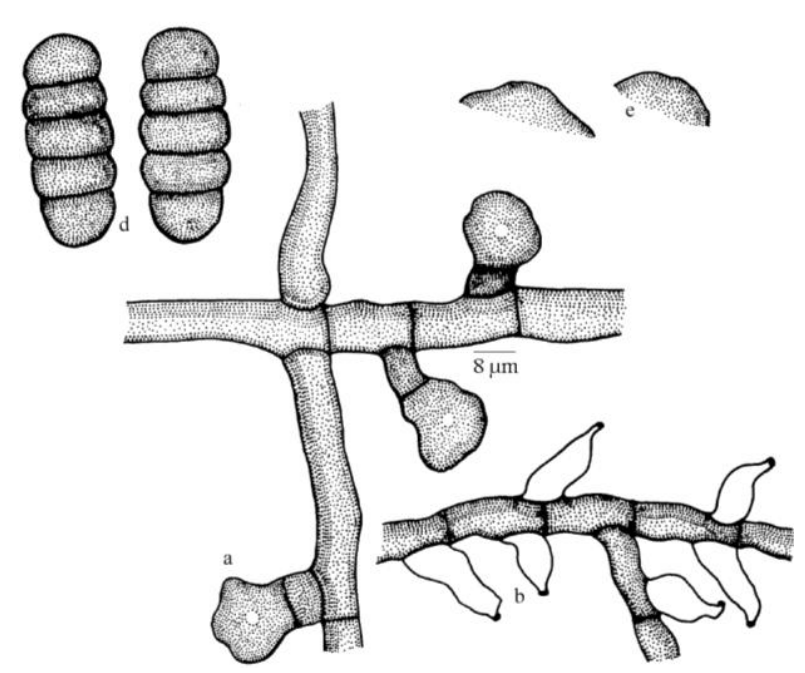

Fig. 6 - Asteridiella xyliae
Colonies epiphyllous, subdense, up to 1 $\mathrm{mm}$ in diameter. Hyphae substraight to slightly flexuous, branching alternate to opposite at acute to wide angles, loosely reticulate, cells 14-35 × 7-9 $\mu \mathrm{m}$. Appressoria alternate, rarely unilateral, antrorse, subantrorse to rarely retrorse, 20-26 $\mu \mathrm{m}$ long; stalk cells cylindrical to cuneate, 4-9 $\mu \mathrm{m}$ long; head cells ovate to globose, entire to angular to slightly lobate, 12-16 × 9-14 $\mu \mathrm{m}$. Phialides mixed with appressoria, alternate to opposite, ampulliform, 17-26 × 6-8 $\mu \mathrm{m}$. Perithecia scattered, up to $120 \mu \mathrm{m}$ in diameter; ascospores oblong to cylindrical, 4-septate, slightly constricted at the septa, 36-40 × 12-16 $\mu \mathrm{m}$.

Materials examined - Kerala, Thiruvananthapuram, Mylamood, on leaves of Xylia xylocarpa Roxb. (Mimosaceae), 6 March 2008, V.B. Hosagoudar \& al. TBGT 6242a (holotype).

Based on the digital formula 3101.3220, this species can be compared with Asteridiella piptadenicola Hansf. known on Piptedemia peregrina from San Domingo but differs from it in having straight hyphae and numerous appressoria (Hansford 1961).

Asterina tragiae V.B. Hosagoudar \& C. Jagath Timmaih sp. nov. MB no. 803122

Fig. 7 Etymology - Named after the host genus.

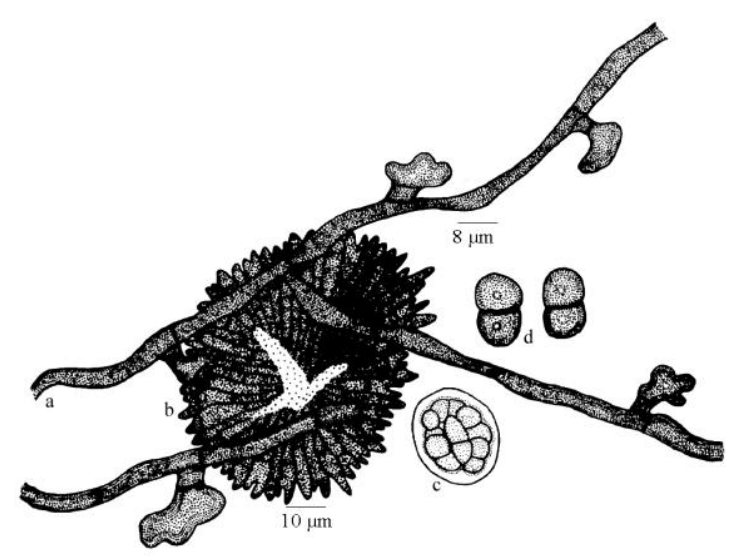

Fig. 7 - Asterina tragiae

Colonies epiphyllous, subdense, spreading, up to $2 \mathrm{~mm}$ in diameter. Hyphae straight to substraight, branching mostly alternate at acute angles, loosely reticulate, cells $17-25 \times 2-3 \mu \mathrm{m}$. Appressoria 2-celled, 
distantly placed, mostly perpendicular to the hyphae, 12-15 $\mu \mathrm{m}$ long; stalk cells cylindrical to cuneate, 5-7 $\mu \mathrm{m}$ long; head cells ovate to globose, straight to often variously curved, irregularly angular to sublobate, $7-10 \times 5-8$ $\mu \mathrm{m}$. Thyriothecia scattered, up to $70 \mu \mathrm{m}$ in diameter, stellately dehisced at the centre; ascospores brown, conglobate, oblong, 1septate, constricted at the septum, rounded at both ends, $12-15 \times 10-12 \mu \mathrm{m}$., wall smooth.

Materials examined - Karnataka, Kodagu, Medikari, on leaves of Tragia sp. (Euphorbiaceae), 1 January 2010, C. Jagath Thimmaiah TBGT 6238c (holotype).

Straight to curved and entire to variously lobate head cells of the appressoria distinguishes this species from others (Hosagoudar 1912).

Asterina xyliae V.B. Hosagoudar sp. nov.

Fig. 8

MB no. 803123

Etymology - Named after the host genus.

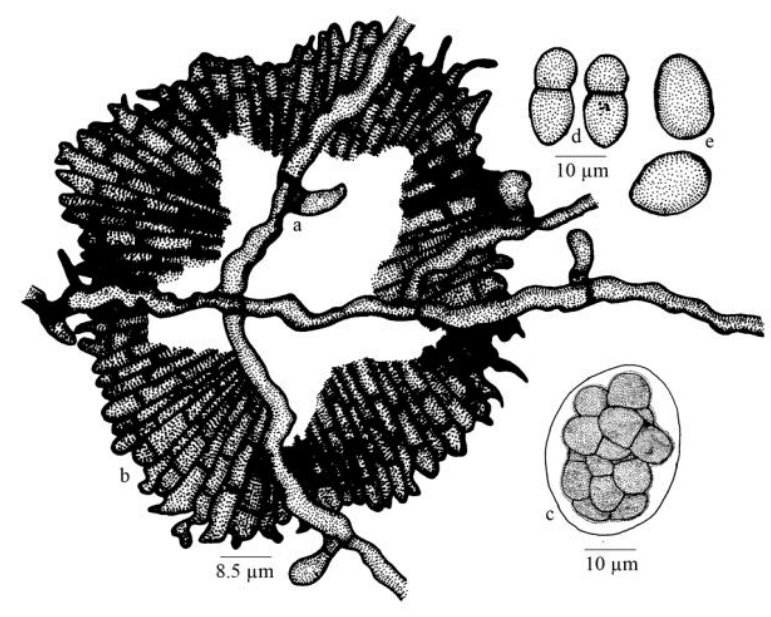

Fig. 8 - Asterina xyliae

Colonies epiphyllous, subdense, up to 2 $\mathrm{mm}$ in diameter. Hyphae substraight to flexuous, branching opposite, alternate to unilateral at acute to wide angles, loosely reticulate, cells $13-22 \times 7-9 \mu \mathrm{m}$. Appressoria scattered, alternate, unilateral, up to $1 \%$ opposite, 10-14 $\mu \mathrm{m}$ long; stalk cells cylindrical to cuneate, 5-6 $\mu \mathrm{m}$ long; head cells ovate, clavate, globose, straight to slightly curved, entire, 5-8 $\times 3-8 \mu \mathrm{m}$. Thyriothecia scattered, orbicular, up to $80 \mu \mathrm{m}$ in diameter, stellately dehisced at the centre, margin crenate; asci ovate to globose, up to $30 \mu \mathrm{m}$ in diameter; ascospores oblong, conglobate, uniseptate, slightly constricted at septum, upper cells ovate and the lower cells globose, broadly rounded at both ends, 11-16 × 5-10 $\mu \mathrm{m}$, wall smooth; pycnothyriospores, unicellular, globose, ovate, 10-18 × 6-8 $\mu \mathrm{m}$.

Materials examined - Kerala, Thiruvananthapuram, Mylamood, on leaves of Xylia xylocarpa Roxb. (Mimosaceae), 6 March 2008, V.B. Hosagoudar \& al. TBGT 6242b (holotype).

This is the only species known on this host genus.

Meliola celastrigena V.B. Hosagoudar sp. nov.

MB no. 803124

Fig. 9 Etymology - Named after the host genus.

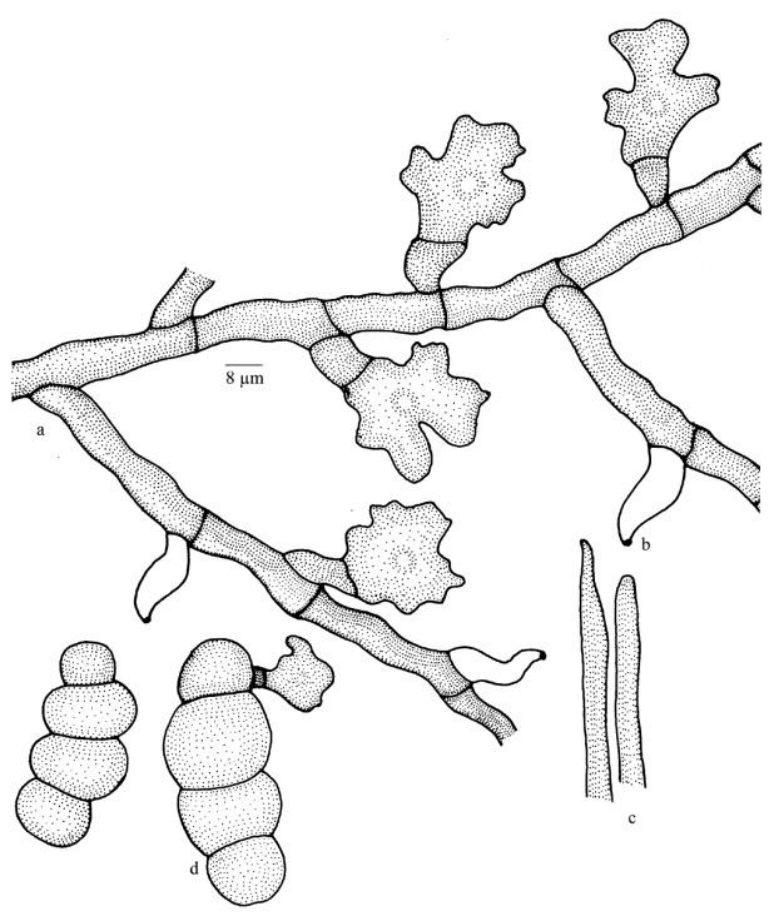

Fig. 9 - Meliola celastrigena

Colonies hypophyllous, dense, velvety, scattered, up to $6 \mathrm{~mm}$ in diameter. Hyphae straight, slightly undulate, branching alternate, unilateral at acute to wide angles, loosely to closely reticulate, cells $19-30 \times 6-9 \mu \mathrm{m}$. Appressoria alternate, antrorse, subantrorse, spreading, retrorse, $37-42 \mu \mathrm{m}$ long; stalk cells cylindrical to cuneate, $11-16 \times 9-10 \mu \mathrm{m}$; head cells ovate, clavate, lobate to stellately lobate, 
24-27 × 24-26 $\mu \mathrm{m}$. Phialides mixed with appressoria, alternate, conoid to ampulliform, 16-35 × 5-9 $\mu \mathrm{m}$; mycelial setae numerous, scattered, simple, acute to obtuse at the tip, 130-430 $\mu \mathrm{m}$ long; perithecia scattered upto $120 \mu \mathrm{m}$ in diameter; ascospores bent, ellipsoidal, 3 septate, deeply constricted at the septa, $57-59 \times 19-21 \mu \mathrm{m}$.

Materials examined - Kerala, Wayanad, Periya, on leaves of Celasteraceae, 15 February 2008, M.C. Riju TBGT 6232 (holotype).

Meliola euonymi G. Stevens ex Hansf. known on Euonymus sp. from Philippines (Hansford 1961) but the present species differs from it in having shorter appressoria (36-42 vs. 40-55 $\mu \mathrm{m}$ ) and ascospores (19-21 vs. 22-24 $\mu \mathrm{m})$.

Meliola glochidiifolia V.B. Hosagoudar sp. nov. Fig. 10

MB no. 803125

Etymology - Named after the host genus.

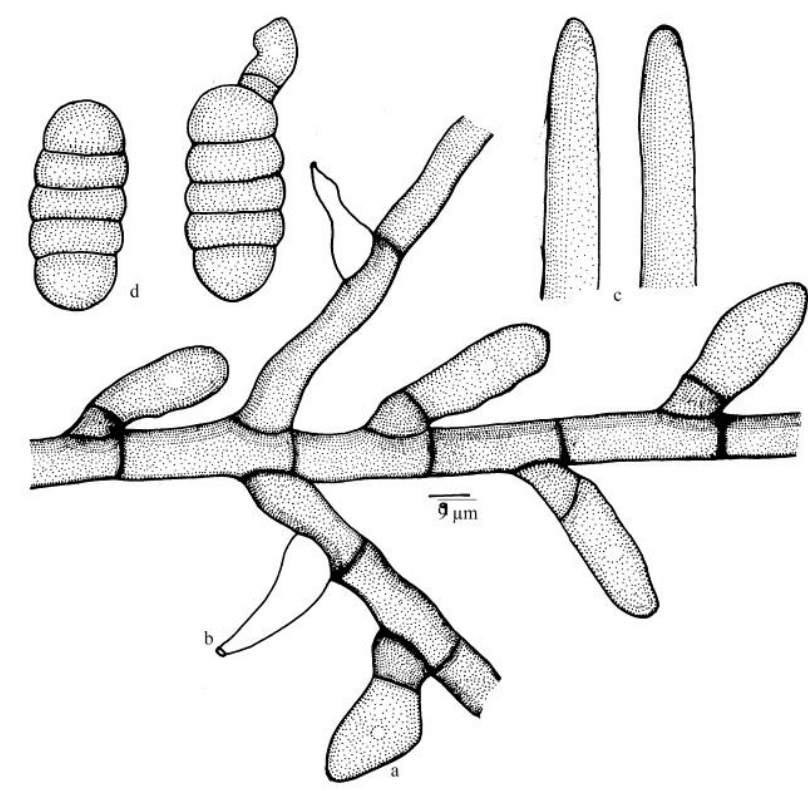

Fig. 10 - Meliola glochidiifolia

Colonies epiphyllous, subdense, up to 2 $\mathrm{mm}$ in diameter. Hyphae straight, branching alternate to opposite at acute angles, loosely to closely reticulate, cells 19-29 × 9-11 $\mu \mathrm{m}$. Appressoria alternate to unilateral, antrorse, 28-32 $\mu \mathrm{m}$ long; stalk cells cylindrical to cuneate, 4-8 $\mu \mathrm{m}$ long; head cells oblong to cylindrical, entire, 20-26 × 11-13 $\mu \mathrm{m}$.
Phialides mixed with appressoria, alternate, ampulliform, 19-26 × 8-11 $\mu \mathrm{m}$. Mycelial setae numerous, scattered, simple, straight, obtuse at the tip, up to $950 \mu \mathrm{m}$ long. Perithecia scattered, up to $190 \mu \mathrm{m}$ in diameter; ascospores oblong to cylindrical, 4-septate, slightly constricted at septa, 48-51 × 14-18 $\mu \mathrm{m}$.

Materials examined - Kerala, Palakkad, Silent Valley National Park, Walakad, on leaves of Glochidion sp. (Euphorbiaceae), 8 August 2008, M.C. Riju \& al. TBGT 6234 (holotype).

Meliola glochidiicola W. Yamam. and M. glochidii var. velutini Hosag. are known on this host genus from the Western Ghats of peninsular India (Hosagoudar 1996). However, it differs from both in having only alternate appressoria with oblong and entire head cells.

Meliola goniothalamigena V.B. Hosagoudar \& C. Jagath Timmaih sp. nov.

Fig. 11 MB no. 803126

Etymology - Named after the host genus.

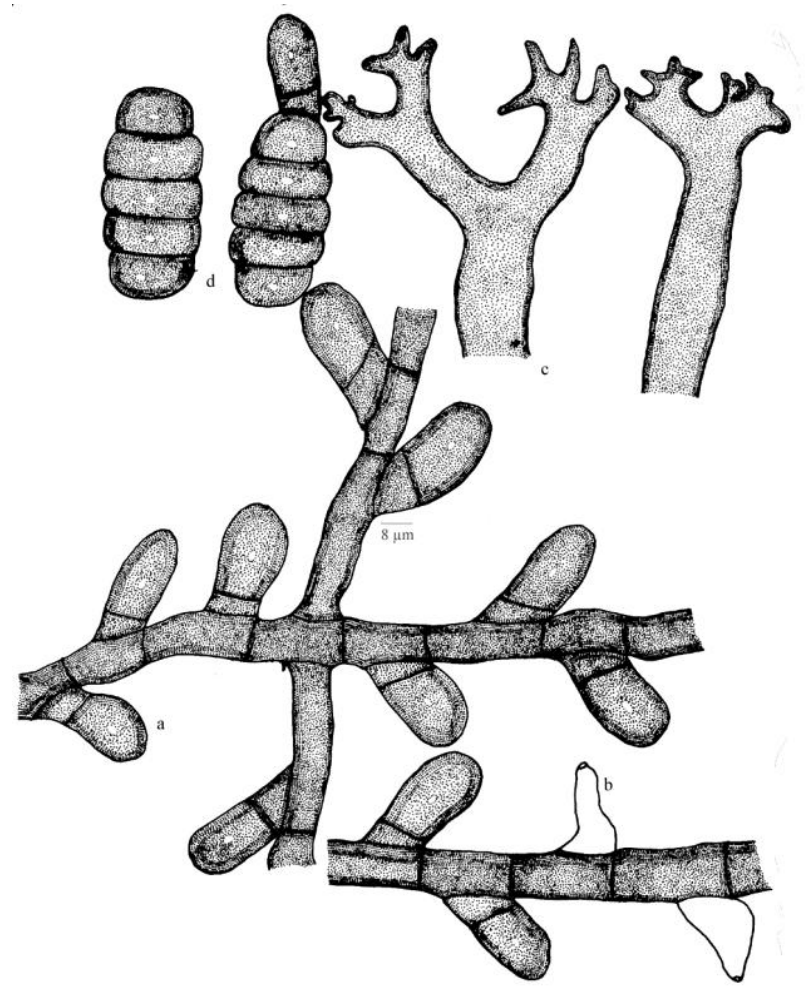

Fig. 11 - Meliola goniothalamigena

Colonies amphigenous, subdense, scattered, up to $1 \mathrm{~mm}$ in diameter. Hyphae straight to substraight, branching mostly opposite, rarely 
alternate at acute to wide angles, loosely to closely reticulate, cells $20-27 \times 5-8 \mu \mathrm{m}$. Appressoria alternate to unilateral, antrorse to subantrorse, straight to rarely curved, 22-27 $\mu \mathrm{m}$ long; stalk cells cylindrical to cuneate, 5-7 $\mu \mathrm{m}$ long; head cells ovate to oblong, often attenuated to truncate the tip, entire, 15-20 $\times$ 7-12 $\mu \mathrm{m}$. Phialides mixed with appressoria, alternate to opposite, ampulliform, 17-27 $\times 6$ $7 \mu \mathrm{m}$. Mycelial setae densely scattered, dichotomously and irregularly furcated, branchlets recurved, acute to dentate at the tip, up to $270 \mu \mathrm{m}$ long. Perithecia scattered, up to $160 \mu \mathrm{m}$ in diameter; ascospores oblong to cylindrical, 4-septate, slightly constricted at septa, 40-45 × 17-20 $\mu \mathrm{m}$.

Materials examined - Karnataka, Kodagu, Medikari, on leaves of Goniothalamus cardiopetalus (Dalz.) Hook. f. \& Thomson (Annonaceae), 8 January 2010, C. Jagath Thimmaiah TBGT 6240 (holotype).

This species differs from all the Meliola species known on members of the family Annonaceae in having dichotomously and repeatedly furcated apical portion of the mycelial setae.

Meliola jasminigena V.B. Hosagoudar sp. nov. Fig. 12

MB no. 803127

Etymology - Named after the host genus.

Colonies epiphyllous, thin, scattered, up to $1 \mathrm{~mm}$ in diameter. Hyphae crooked, branching alternate to opposite at acute to wide angles, loosely to very closely reticulate, cells 16-22 × 6-10 $\mu \mathrm{m}$. Appressoria alternate to unilateral, antrorse, subantrorse to retrorse, straight to curved, 19-29 $\mu \mathrm{m}$ long; stalk cells cylindrical to cuneate, 4-10 $\mu \mathrm{m}$ long; head cells ovate, clavate, oblong to cylindrical, entire, angular and crenately lobate to sublobate, $16-22 \times 12-16 \mu \mathrm{m}$. Phialides mixed with appressoria, alternate, ampulliform, 17-24 $\times 6-10 \mu \mathrm{m}$. Mycelial setae numerous, simple, straight, acute at the tip, up to $410 \mu \mathrm{m}$ long. Perithecia scattered, up to $110 \mu \mathrm{m}$ in diameter; ascospores cylindrical, 4-septate, slightly constricted at septa, $48-50 \times 15-18 \mu \mathrm{m}$.

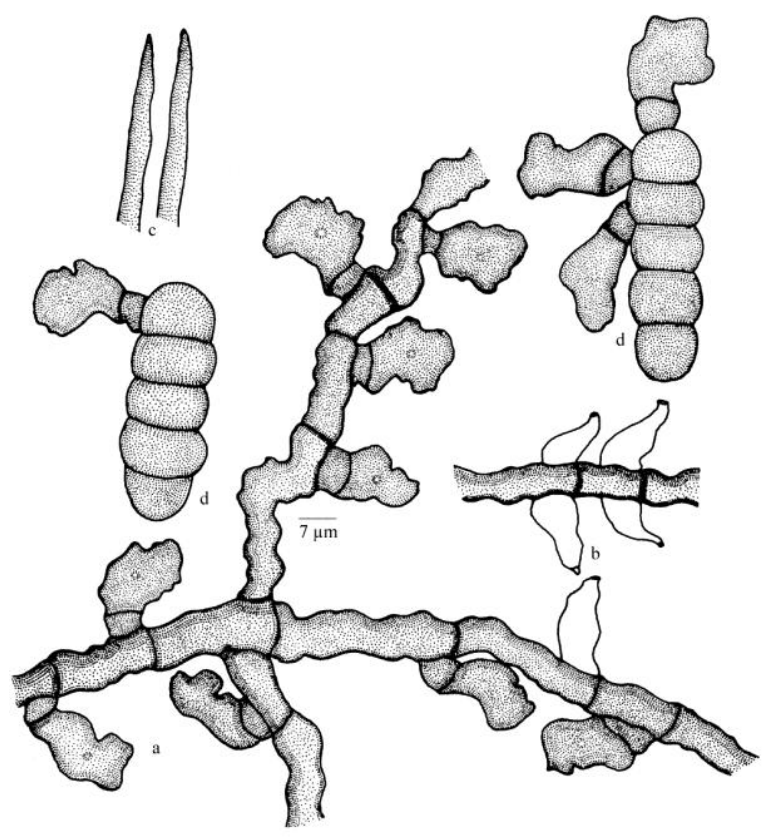

Fig. 12 - Meliola jasminigena

Materials examined - Kerala, Wayanad, Periya, on leaves of Jasminum bignoniaceum Wallich ex DC. (Oleaceae), 2 January 2010, M.C. Riju TBGT 6231(holotype).

This species is similar to Meliola jasminicola var. africana Hansf. in having crooked mycelium and in the morphology of appressoria. However, it differs in having phialides mixed with appressoria, longer ascospores (48-50 vs. 31-39 $\mu \mathrm{m}$ ).

Meliola phyllanthigena V.B. Hosagoudar sp. nov. Fig. 13 MB no. 803128

Etymology - Named after the host genus.

Colonies epiphyllous, subdense, up to 2 $\mathrm{mm}$ in diameter. Hyphae straight to substraight, branching alternate to opposite at acute to wide angles, closely and densely reticulate, cells 16$27 \times 6-10 \mu \mathrm{m}$. Appressoria densely arranged, alternate, antrorse, subantrorse to closely antrorse, 25-34 $\mu \mathrm{m}$ long; stalk cells cylindrical to cuneate, 6-13 $\mu \mathrm{m}$ long; head cells ovate, globose, entire, 17-22 × 11-15 $\mu \mathrm{m}$. Phialides mixed with appressoria, alternate to opposite, ampulliform, 22-29 × 6-10 $\mu \mathrm{m}$. Mycelial setae numerous, closely scattered, simple, straight, about $10 \%$ uncinate, acute at the tip, up to 300 


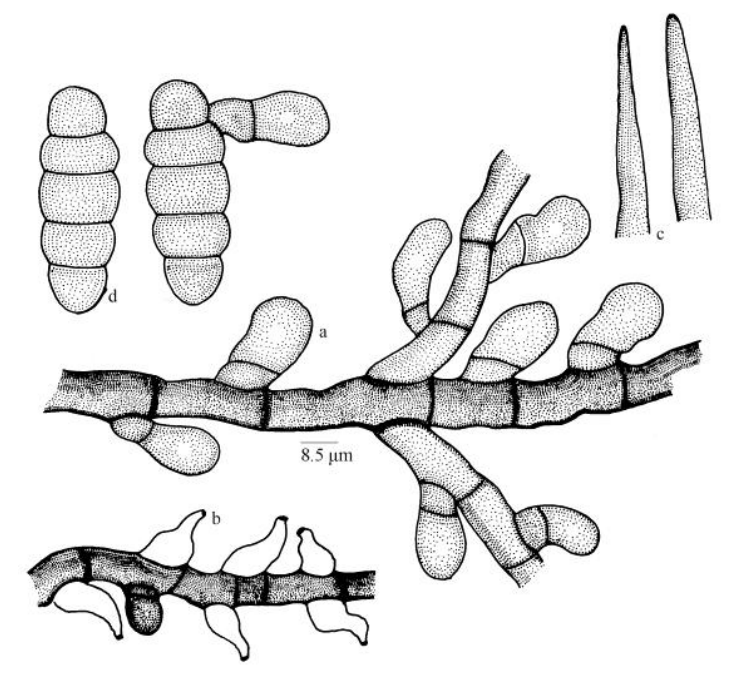

Fig. 13 - Meliola phyllanthigena

$\mu \mathrm{m}$ long. Perithecia scattered, up to $130 \mu \mathrm{m}$ in diameter; ascospores oblong to cylindrical, 4septate, slightly constricted at septa, 48-51 $\times$ $18-20 \mu \mathrm{m}$.

Materials examined - Kerala, Wayanad, Periya, on leaves of Phyllanthus sp. (Euphorbiaceae), 2 February 2008, M.C. Riju \& al. TBGT 6233 (holotype).

This is a unique species of the genus known on the members of Euphorbiaceae in having uncinate mycelial setae (Hansford 1961).

Meliola pygeicola V.B. Hosagoudar sp. nov.

MB no. 803129

Fig. 14 genus.

Etymology - Named after the host

Colonies epiphyllous, thin, scattered, up to $6 \mathrm{~mm}$ in diameter. Hyphae straight to substraight, branching opposite at acute to wide angles, loosely reticulate, cells $16-32 \times 6-10$ $\mu \mathrm{m}$. Appressoria alternate, opposite to unilateral, straight to curved, antrorse to subantrorse, 12-21 $\mu \mathrm{m}$ long; stalk cells cylindrical to cuneate, 3-6 $\mu \mathrm{m}$ long; head cells globose, ovate, ampulliform, entire, 9-16 × 6$10 \mu \mathrm{m}$. Phialides mixed with appressoria, opposite to unilateral, ampulliform, 16-22 $\times 4$ $11 \mu \mathrm{m}$. Mycelial setae numerous, simple, acute, bi to tri-dentate, up to $750 \mu \mathrm{m}$ long. Perithecia scattered, up to $140 \mu \mathrm{m}$ in diameter; ascospores cylindrical, 4-septate, slightly constricted at the septa, $36-40 \times 12-15 \mu \mathrm{m}$.

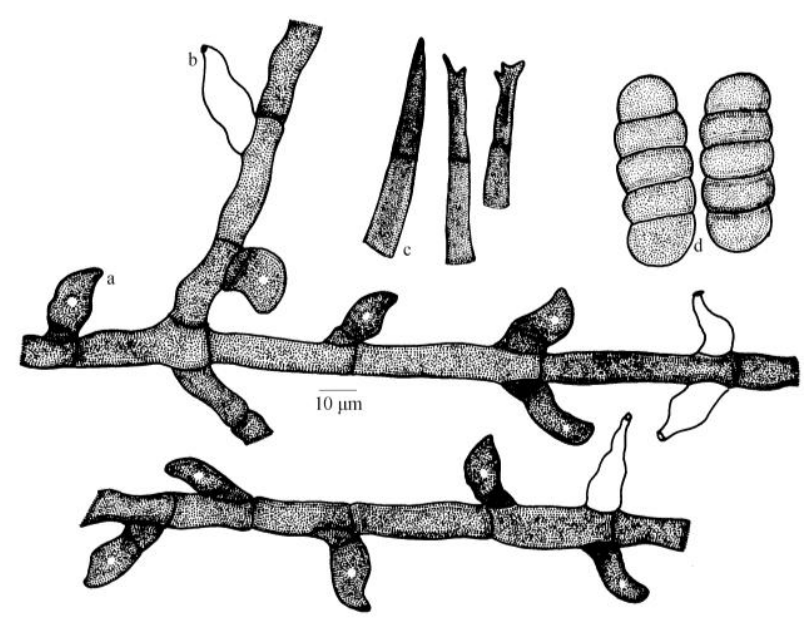

Fig. 14 - Meliola pygeicola

Materials examined - Kerala, Pathanamthitta, Nilakal Forest, on leaves of Pygeum sp. (Rosaceae), 27 March 2009, Robin P.J. \& al. TBGT 6244 (holotype).

Asteridiella pygei Hansf. known on this host from South Africa differs from it in having mycelial setae (Hansford 1961). It differs from all other Meliola species known on the members of Rosaceae in having globose to ampulliform head cells of appressoria.

Meliola tragiae V.B. Hosagoudar \& C. Jagath Timmaih sp. nov.

Fig. 15

MB no. 803130 genus.

Etymology - Named after the host

Colonies epiphyllous, subdense, up to 2 $\mathrm{mm}$ in diameter, confluent. Hyphae straight, substraight to flexuous, branching opposite to irregular at wide angles, loosely reticulate, cells 22-27 × 5-6 $\mu \mathrm{m}$. Appressoria alternate, about $1 \%$ opposite, straight to slightly curved, antrorse to subantrose,12-20 $\mu \mathrm{m}$ long; stalk cells cylindrical to cuneate, 2-7 $\mu \mathrm{m}$ long; head cells ovate, globose, entire, straight to curved, rarely truncate at the apex, 10-15 × 7-10 $\mu \mathrm{m}$. Phialides mixed with appressoria, alternate to opposite, conoid to ampulliform, $12-20 \times 5-7$ $\mu \mathrm{m}$. Mycelial setae numerous, simple, straight, obtuse, 2-3-times variously and irregularly dentate, often furcate at the tip, about $10 \%$ uncinate, up to $470 \mu \mathrm{m}$ long. Perithecia scattered, up to $110 \mu \mathrm{m}$ in diameter; ascospores oblong, cylindrical, 4-septate, constricted at septa, $35-40 \times 12-15 \mu \mathrm{m}$. 


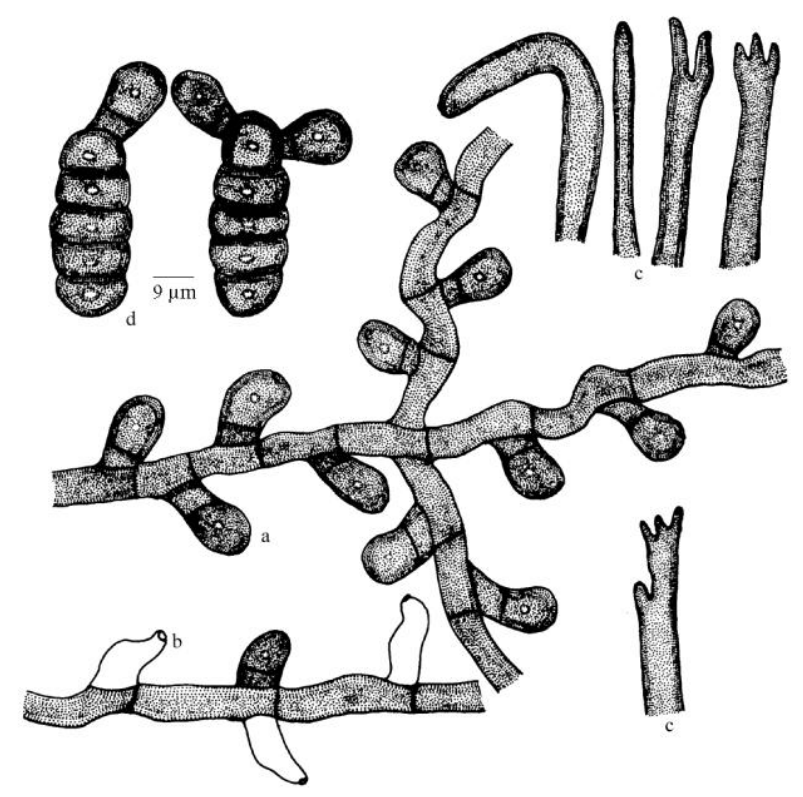

Fig. 15 - Meliola tragiae

Materials examined - Karnataka, Kodagu, Medikari, on leaves of Tragia sp. (Euphorbiaceae), 1 January 2010, C. Jagath Thimmaiah TBGT 6238a (holotype).

Meliola jamaicensis Hansf., $M$. alchorneae F. Stevens \& Tehon, M. brideliae F. Stevens \& Roldan and M. crotonismacrostachydis Hansf. have simple to dentate mycelial setae. However, the present species differs from all in having uncinate mycelial setae. It also differs from $M$. euphorbiae $\mathrm{F}$. Stevens \& Tehon in having dentate mycelial setae (Hansford 1961).

Prillieuxina loranthi (Syd. \& P. Syd.) Syd., Philippine J. Sci. 21(2): 141, 1922.

Asterinella loranthi Syd. \& P. Syd., Philippine J. Sci. C. 8: 490, 1913.

Asterostomula loranthi Theiss., Ann. Mycol. 14: 270, 1916; Hosagoudar, Sabeena and A, Jacob-Thomas, Plant Pathology \& Quarantine 1(1):7, 2011.

Fig. 16

Colonies amphigenous, subdense to dense, up to $4 \mathrm{~mm}$ in diameter, confluent. Hyphae flexuous to crooked, branching irregular at acute to wide angles, closely lacking. Thyriothecia scattered to connate, orbicular, up to $120 \mu \mathrm{m}$ in diameter, stellately dehisced at the centre, margin crenate to fimbriate; asci globose, octosporous, up to 29 $\mu \mathrm{m}$ in diameter; ascospores conglobate, uniseptate, constricted at the septum, 20-22 $\times$
10-15 $\mu \mathrm{m}$. Pycnothyria many, orbicular, joined together marginally, up to $180 \mu \mathrm{m}$ in diameter, dehiscing stellately at the centre, margin crenate to fimbriate, fringed hyphae flexuous; pycnothyriospores unicellular, pyriform, ovate, 20-25 × 12-17 $\mu \mathrm{m}$, wall smooth.

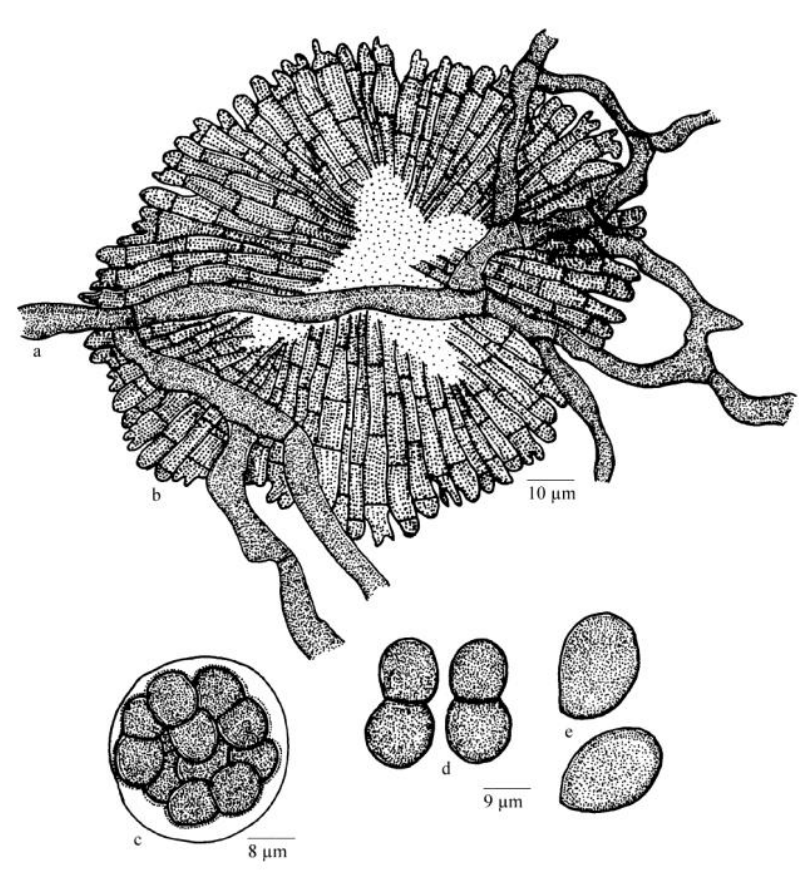

Fig. 16 - Prillieuxina loranthi

Materials examined - Kerala, Wayanad, Periya, Gurukulam Botanic Garden, on leaves of Loranthus sp. (Loranthaceae). 5 November 2009, A. Sabeena \& M.C. Riju TBGT 6243.

This fungus mostly persists in its anamorph state but a few thyriothecia are mixed with pycnothyria. This species was reported from Philippines and is reported here for the first time from India (Hosagoudar 2012).

\section{Acknowledgements}

Thanks are due to Dr. P.G. Latha, Director, JNTBGRI, Palode for the facilities. Mrs. Divya Babu and Mrs. Fatima, Research Scholars of this section are acknowledged for their assistance.

\section{References}

Hansford CG. 1961. The Meliolineae. A Monograph. Sydowia, Beihefte 2, 1806. 
Plant Pathology \& Quarantine - Doi 10.5943/ppq/3/1/1

Hosagoudar VB. 1996. Meliolales of India Botanical Survey of India, Calcutta, pp. 363.

Hosagoudar VB. 2008. Meliolales of India.
Vol. II. Botanical Survey of India, Calcutta, pp. 390.

Hosagoudar VB. 2012. Asterinales of India. Mycosphere 2(5), 617-852 